\title{
EFEKTIVITAS PERMENKES NO. 71 TAHUN 2013 TERHADAP PELAYANAN OBAT PESERTA BADAN PENYELENGGARA J AMINAN SOSIAL KESEHATAN (Studi di Puskesmas Kabupaten Ciamis) Vina Nur Syaidah H
}

(Dosen Stikes Muhamadiyah Ciamis, Email: vina.nursyaidah.hidayat@gmail.com)

\begin{abstract}
This study aims to analyze the effectiveness of Decree No. 71 Year 2013 on drug services in Puskesmas participants BPJ S Ciamis Regency and analyze inhibiting the implementation of Decree No. 71 Year 2013 on drug services in Puskesmas participants BPJ S Ciamis District.

Legal research that will be done is the type of sociological studies. Sources of data include primary data in this study in the form of opinion from respondents in this case include the Chief Medical Officer of Ciamis, 6 (six) health center in the district of Ciamis, Head of the Social Security Agency of Health Ciamis, and Participant Social Security Agency of Health, while secondary data sources in the form of legislation, literature and official documents relating to the subject matter.

The results of the study explained that Decree No. 71 Year 2013 About the Health Care to Care Medicine at the health center Ciamis Regency has not been effective, as seen from the size of the observance of a rule of law, it appears the subject of law, namely health centers in the district of Ciamis of 6 (six) of clinics 2 (two) puskesmas devout implement these rules, there are four (4) health centers were not obedient in implementing the regulation, so that the purpose of Decree No. 71 Year 2015 that participants benefited health care and protection to meet basic health needs were not met.

The results of the study explained that Decree No. 71 Year 2013 About the Health Care to Care Medicine at the health center Ciamis Regency has not been effective, as seen from the size of the observance of a rule of law, it appears the subject of law, namely health centers in the district of Ciamis of 6 (six) of clinics 2 (two) puskesmas devout implement these rules, there are four (4) health centers were not obedient in implementing the regulation, so that the purpose of Decree No. 71 Year 2015 that participants benefited health care and protection to meet basic health needs were not met.

Factors - factors inhibiting the implementation of Decree No. 71 Year 2013 on drug service participants BPJ S in Puskesmas Ciamis, among other rules or its own laws collide with a variety of health professions, void of drugs in industrial plants such drugs, human resources visible from education less coaching in exercising its rights and obligations, and the people considered officers and officials do not obey the rules so that there is disappointment with the participants BPJ S, so it tends to affect disobedience in compliance with the regulations in the payment of dues each month.
\end{abstract}

Keywords: Drugs Service, Effectiveness, Health Center

\section{Abstrak}

Penelitian ini bertujuan menganalisa Efektivitas Permenkes Nomor 71 Tahun 2013 terhadap pelayanan obat peserta BPJS Kesehatan di Puskesmas Kabupaten Ciamis dan menganalisa penghambat pelaksanaan Permenkes Nomor 71 Tahun 2013 terhadap pelayanan obat peserta BPJS Kesehatan di Puskesmas Kabupaten Ciamis.

Penelitian hukum yang akan dilakukan adalah tipe kajian sosiologis. Sumber data meliputi data primer yang dalam penelitian ini berupa pendapat langsung dari responden dalam hal ini meliputi Kepala Dinas Kesehatan Kabupaten Ciamis, 6 (enam) Puskesmas di Kabupaten Ciamis, Kepala Badan Penyelenggara Jaminan Sosial Kesehatan Kabupaten Ciamis, dan Peserta Badan Penyelenggara Jaminan Sosial Kesehatan, sedangkan sumber data sekunder berupa peraturan perundang-undangan, literatur dan dokumen resmi yang berkaitan dengan pokok permasalahannya. 
Hasil penelitian menjelaskan bahwa Permenkes Nomor 71 Tahun 2013 Tentang Pelayanan Kesehatan terhadap Pelayanan Obat di Puskesmas Kabupaten Ciamis belum efektif, karena dilihat dari tingkat ukuran ketaatan suatu aturan perundangundangan, terlihat subjek hukum yaitu puskesmas di Kabupaten Ciamis dari 6 (enam) puskesmas terdapat 2 (dua) puskesmas yang taat melaksanakan peraturan tersebut, namun ada 4 (empat) puskesmas yang tidak taat dalam melaksanakan peraturan tersebut, sehingga tujuan dari Permenkes Nomor 71 Tahun 2015 yaitu peserta memperoleh manfaat pemeliharaan kesehatan dan perlindungan dalam memenuhi kebutuhan dasar kesehatan itu tidak tercapai.

Hasil penelitian menjelaskan bahwa Permenkes Nomor 71 Tahun 2013 Tentang Pelayanan Kesehatan terhadap Pelayanan Obat di Puskesmas Kabupaten Ciamis belum efektif, karena dilihat dari tingkat ukuran ketaatan suatu aturan perundangundangan, terlihat subjek hukum yaitu puskesmas di Kabupaten Ciamis dari 6 (enam) puskesmas terdapat 2 (dua) puskesmas yang taat melaksanakan peraturan tersebut, namun ada 4 (empat) puskesmas yang tidak taat dalam melaksanakan peraturan tersebut, sehingga tujuan dari Permenkes Nomor 71 Tahun 2015 yaitu peserta memperoleh manfaat pemeliharaan kesehatan dan perlindungan dalam memenuhi kebutuhan dasar kesehatan itu tidak tercapai.

Faktor - factor penghambat pelaksanaan Permenkes Nomor 71 Tahun 2013 terhadap pelayanan obat peserta BPJS Kesehatan di Puskesmas Kabupaten Ciamis, antara lain aturan atau hukumnya sendiri berbenturan dengan berbagai profesi kesehatan, kekosongan obat di pabrik industri obat tersebut, sumber daya manusia yang terlihat dari pendidikan yang kurang pembinaan dalam melaksanakan hak dan kewajibannya, dan masyarakat menganggap petugas dan pejabatnya tidak taat peraturan sehingga ada kekecewaan terhadap peserta BPJS Kesehatan, sehingga cenderung berdampak terhadap ketidaktaatan dalam memenuhi peraturan dalam pembayaran iuran tiap bulannya.

Kata Kunci :Efektivitas, Puskesmas, Pelayanan Obat

\section{PENDAHULUAN}

$\begin{array}{clr}\text { Pusat } & \text { Kesehatan } & \text { Masyarakat } \\ \text { (Puskesmas) adalah suatu kesatuan }\end{array}$
organisasi fungsional yang merupakan pusat pengembangan kesehatan masyarakat yang juga membina peran serta masyarakat disamping memberikan pelayanan secara menyeluruh dan terpadu kepada masyarakat di wilayah kerjanya dalam bentuk kegiatan pokok. Puskesmas juga dapat didefinisikan sebagai unit pelaksana tekhnis dinas kesehatan Kabupaten/Kota yang bertanggungjawab menyelenggarakan pembangunan kesehatan di suatu wilayah kerja, dengan kata lain puskesmas mempunyai wewenang dan tanggung jawab atas pemeliharaan kesehatan masyarakat dalam wilayah kerjanya. Pelayanan kesehatan yang diberikan puskesmas merupakan pelayanan kesehatan yang menyeluruh meliputi pelayanan kuratif (pengobatan), preventif (upaya pencegahan), promotif (peningkatan kesehatan), dan rehabilitatif (pemulihan kesehatan). ${ }^{1}$

Puskesmas merupakan fasilitas
tingkat pertama yang menyelenggarakan pelayanan kesehatan yang bekerjasama dengan BPJS (Badan Penyelenggara Jaminan Sosial) Kesehatan dengan melalui perjanjian kerjasama. Perjanjian kerjasama antara fasilitas kesehatan dan BPJS Kesehatan didalamnya memuat hak dan kewajiban kedua belah pihak. Hak fasilitas kesehatan diantaranya

Ferry Efendi dan Makhfudli, 2009, Keperawatan Kesehatan Komunitas: Teori dan Praktik dalam Keperawatan, Jakarta:Salemba Medika, hlm. 275-277 
yaitu mendapatkan informasi tentang kepesertaan, prosedur pelayanan, pembayaran dan proses kerja sama dengan BPJS Kesehatan serta menerima pembayaran klaim atas pelayanan yang diberikan kepada peserta paling lambat 15 (lima belas) hari kerja sejak dokumen klaim diterima lengkap. Kewajiban fasilitas kesehatan adalah memberikan pelayanan kesehatan kepada peserta sesuai ketentuan yang berlaku dan memberikan laporan pelayanan sesuai waktu dan jenis yang telah disepakati. ${ }^{2}$

Pelayanan farmasi merupakan Pelayanan Kefarmasian yang langsung dan bertanggung jawab kepada pasien berkaitan dengan Obat dan Bahan Medis Habis Pakai dengan maksud mencapai hasil yang pasti untuk meningkatkan mutu kehidupan pasien. Pelayanan obat di Puskesmas ini meliputi dua hal tersebut, dimana dalam penelitian ini lebih ditekankan dalam manajerial pengelolaan obat dan bahan medis habis pakai dikarenakan dari banyaknya keluhan peserta BPJS (Badan Penyelenggara Jaminan Sosial) Kesehatan Ciamis dimana adanya kekurangan ketersediaan obat yang ada di fasilitas tingkat pertama yaitu Puskesmas yang dimana telah diatur pada Permenkes Nomor 71 Tahun 2013 tentang faskes tingkat pertama wajib memberikan pelayanan obat kepada peserta BPJSKesehatan sesuai indikasi medis dan sesuai obat formularium nasional.

Puskesmas merupakan fasilitas

kesehatan tingkat pertama yang menyelenggarakan pelayanan kesehatan untuk JKN (Jaminan Kesehatan Nasional). Peserta BPJS (Badan Penyelenggaraan Jaminan Sosial) Kesehatan berhak

\footnotetext{
${ }^{2}$ Pasal 12 ayat (1-6) Peraturan Menteri Kesehatan Nomor 71 Tahun 2013 Tentang Pelayanan Kesehatan pada Jaminan Kesehatan Nasional
}

mendapatkan pelayanan kesehatan secara komprehensif di faskes tingkat pertama ini. Pelayanan kesehatan tersebut meliputi salah satunya adalah pelayanan obat. Berdasarkan pra penelitian telah ditemukan 10 (sepuluh) form keluhan peserta BPJS Kesehatan Tahun 2015 yang ada di kantor BPJS Kesehatan Ciamis, dimana banyak yang mengeluhkan pada faskes tingkat pertama khususnya di puskesmas tidak mendapatkan haknya dalam pelayanan obat terutama obat yang ada di fornas (Formularium Nasional). Beberapa keluhan tersebut mendorong peneliti untuk meneliti di fasilitas kesehatan pertama (puskesmas) yang berada di Kabupaten Ciamis.

Dilihat dari hasil pra penelitian di BPJS Kesehatan Ciamis ada dugaan bahwa pelayanan obat di fasilitas kesehatan pertama belum sesuai dengan Permenkes Nomor 71 Tahun 2013. Berdasarkan hal tersebut, maka penting dilakukan penelitian tentang Efektivitas Permenkes Nomor 71 Tahun 2013 terhadap pelayanan obat peserta BPJS Kesehatan dikarenakan peserta berhak memperoleh pelayanan obat yang disediakan di fasilitas tingkat pertama sesuai dengan Fornas (Formularium Nasional).

Pelayanan obat tersebut apabila tidak diberikan oleh fasilitas kesehatan pertama berarti BPJS Kesehatan berhak menghentikan perjanjian kerjasama dengan fasilitas kesehatan tingkat pertama tersebut, dikarenakan sudah merugikan peserta yang telah membayar iuran atau iurannya dibayar oleh pemerintah. Permenkes Nomor 71 Tahun 2013 ini juga mengatur bahwa dengan permenkes tersebut adanya jaminan kesehatan untuk peserta yang bertujuan melindungi kesehatan supaya peserta 
memperoleh manfaat pemeliharaan kesehatan dan perlindungan dalam memenuhi kebutuhan dasar kesehatan yang diberikan kepada setiap orang yang telah membayar iuran atau iurannya dibayar oleh pemerintah. Kerugian peserta apabila tidak terpenuhi kebutuhan pelayanan dasar tersebut khususnya pelayanan obat maka tujuan dari Permenkes Nomor 71 Tahun 2013 tidak tercapai.

Mempertimbangkan adanya kerugian peserta dalam memperoleh pelayanan kesehatan terutama dalam pelayanan ketersediaan obat di faskes tingkat pertama (puskesmas), hal inilah yang menjadi urgensi perlu adanya penelitian tesis yang berjudul "Efektivitas Permenkes Nomor 71 Tahun 2013 Terhadap Pelayanan Obat Peserta Badan Penyelenggara Jaminan Sosial Kesehatan (Studi di Puskesmas Kabupaten Ciamis)".

\section{PERUMUSAN MASALAH}

Berdasarkan latar belakang di atas maka dapat dirumuskan permasalahan sebagai berikut: Pertama, bagaimanakah Efektivitas Permenkes Nomor 71 Tahun 2013 terhadap pelayanan obat peserta BPJS Kesehatan di Puskesmas Kabupaten Ciamis. Kedua, Halhal apakah yang menjadi penghambat pelaksanaan Permenkes Nomor 71 Tahun 2013 terhadap pelayanan obat peserta BPJS Kesehatan di Puskesmas Kabupaten Ciamis.

\section{METODE PENELITIAN}

1. Metode Pendekatan: Yuridis Sosiologis

2. Tipe Penelitian: Deskriptif Analitis

3. Sumber Data: Data primer dan data sekunder

4. Lokasi Penelitian: Puskesmas di KabupatenCiamis
5. Metode Penelitian Informan: Purposive Sampling

6. Metode Pengumpulan Data: Observasi,wawancara,dokumentasi

7. Analisis Data: Kualitatif

\section{PEMBAHASAN}

Efektivitas Permenkes Nomor 71 Tahun

2013 Terhadap Pelayanan Obat Peserta

BPJ S Kesehatan di Puskesmas

\section{Kabupaten Ciamis}

Efektivitas hukum menurut Soerjono Soekanto adalah segala upaya yang dilakukan agar hukum yang ada dalam masyarakat benar-benar hidup dalam masyarakat, artinya hukum tersebut benar-benar berlaku secara yuridis, sosiologis dan filosofis. ${ }^{3}$ Hukum sebagai kaidah merupakan patokan mengenai sikap tindak atau perilaku yang pantas. Metode berpikir yang dipergunakan adalah metode deduktif-rasional sehingga menimbulkan jalan pikiran yang dogmatis. Efektivitas hukum dalam tindakan atau realita hukum dapat diketahui apabila seseorang menyatakan bahwa suatu kaidah hukum berhasil atau gagal mencapai tujuannya maka hal itu biasanya diketahui apakah pengaruhnya berhasil mengatur sikap tindak atau perilaku tertentu sehingga sesuai dengan tujuannya atau tidak. Salah satu upaya supaya masyarakat memenuhi kaidah hukum adalah dengan mencantumkan sanksi-sanksinya. ${ }^{4}$ Masalah efektivitas hukum berkaitan erat dengan masalah kepatuhan terhadap hukum (sebagai norma). Berbagai faktor dapat menjadi sebab mengapa warga-warga masyarakat mentaati hukum. Ketaatan hukum

3 Soerjono Soekanto, 1989, Suatu Tinjauan Sosiologis Hukum Terhadap Masalah-Masalah Sosial, Bandung:Alumni, , hlm. 53

4 Soerjono Soekanto, 1985, Efektivikasi Hukum dan Sanksi- Sanksi, Bandung:Remadja Karya,hlm.1 
sendiri masih dapat dibedakan kualitasnya dalam tiga jenis yakni: ${ }^{5}$

1. Ketaatan yang bersifat compliance, yaitu jika seseorang taat terhadap suatu aturan hanya karena ia takut terkena sanksi.

2. Ketaatan yang bersifat identification, yaitu jika seseorang taat terhadap suatu aturan hanya karena takut hubungan baiknya dengan seseorang menjadi rusak.

3. Ketaatan yang bersifat internalization, yaitu jika seseorang yang taat terhadap suatu aturan benar-benar karena ia merasa aturan itu sesuai dengan nilai-nilai intrinsik yang dianutnya.

Dengan kata lain, mengetahui adanya tiga jenis ketaatan di atas, maka tidak dapat sekadar menggunakan ukuran ditaatinya suatu aturan undang-undang sebagai bukti efektifnya suatu peraturan perundangundangan, paling tidaknya juga harus ada perbedaan kualitas keefektifan suatu aturan atau perundang-undangan. Semakin banyak warga masyarakat yang menaati suatu undang-undang hanya dengan ketaatan yang bersifat compliance atau identification, berarti kualitas keefektifan aturan atau undangundang itu masih rendah; sebaliknya semakin banyak warga masyarakat yang menaati suatu aturan undang-undang dengan ketaatan bersifat internalization, maka semakin tinggi kualitas efektivitas aturan atau undang-undang itu $^{6}$, oleh karena itu dapat disimpulkan bahwa efekifitas hukum dapat dikatakan efektif

\footnotetext{
$5 \quad$ Achmad Ali,dkk, 2012, Menjelajahi Kajian Empiris Terhadap Hukum, Jakarta:Kencana Prenadamedia Group, hlm. 142

Ibid, Achmad Ali,dkk, hal.143
}

apabila subjek-subjek hukum menaati suatu peraturan perundang-undangan sehingga tercapai tujuan dari peraturan perundangundangan tersebut, dalam penelitian ini efektifitas dapat terlihat dari subjek-subjek hukum menati peraturan permenkes Nomor 71 Tahun 2013 Tentang Pelayanan Kesehatan pada Jaminan Kesehatan Nasional terhadap pelayanan obat yang ada di Puskesmas Kabupaten Ciamis sehingga tujuan dari Permenkes Nomor 71 Tahun 2016 yaitu agar peserta BPJS Kesehatan memperoleh manfaat pemeliharaan kesehatan dan perlindungan dalam memenuhi kebutuhan dasar kesehatan dapat tercapai.

Peraturan Menteri Kesehatan Nomor 71 Tahun 2013 Tentang Pelayanan Kesehatan pada Jaminan Kesehatan Nasional pada Pasal 1 ayat 1 menjelaskan tujuan dari peraturan tersebut agar peserta memperoleh manfaat pemeliharaan kesehatan dan perlindungan dalam memenuhi kebutuhan dasar kesehatan yang diberikan kepada setiap orang yang telah membayar iuran atau iurannya dibayar oleh pemerintah.

Menurut Hasil Wawancara dengan Pihak Staff Gudang Farmasi ${ }^{7}$ bahwa Dinas Kesehatan tidak melakukan pengadaan obat dikarenakan itu sudah termasuk ke dalam wewenang Puskesmas dalam Peraturan Presiden Nomor 32 Tahun 2014 Tentang Pengelolaan dan Pemanfaatan Dana Kapitasi Jaminan Kesehatan Nasional (JKN) pada Fasilitas Kesehatan Tingkat Pertama (FKTP), namun Dinas Kesehatan dapat membantu dengan menghadirkan pejabat pengadaan, dimana kepala puskesmas merencanakan kebutuhan obat yang diperlukan

Hasil Wawancara dengan Pihak Staff Gudang Farmasi Dinas Kesehatan Kabupaten Ciamis 
puskesmasnya dan disesuaikan dengan ecathalog kemudian dibantu pemesanan oleh pejabat pengadaan yang ada di Dinas Kesehatan Kabupaten Ciamis. Pejabat pengadaan tersebut harus memiliki sertifikat pelatihan pengadaan barang dan jasa, dimana pejabat pengadaan hanya disediakan di Dinas Kesehatan Ciamis, seharusnya setiap puskesmas mempunyai pejabat pengadaan yang memiliki sertifikat pengadaan barang dan jasa dan seharusnya yang menjadi pejabat pengadaan tersebut adalah Kepala Puskesmas tersebut, namun karena terbatasnya kemampuan untuk mengikuti pelatihan tersebut maka Dinas Kesehatan menyediakan pejabat pengadaan yang telah bersertifikat barang dan jasa untuk sebagai perantara Puskesmas tersebut mengadakan ketersediaan obat di tempatnya.

Menurut Hasil Wawancara Staff Gudang Farmasi untuk pengadaan barang tiap puskesmas rawat inap dan non rawat inap pengadaannya berbeda-beda tergantung kebutuhannya. Puskesmas tersebut biasanya mengadakan kebutuhan obat dengan merencanakan dari sepuluh penyakit terbesar yang berada di daerah sekitar puskesmas tersebut, karena di setiap puskesmas pasti akan berbeda-beda jenis penyakit terbesarnya tergantung daerah sekitar Puskesmas tersebut. ${ }^{8}$

Menurut Hasil Wawancara Staff Pelayanan Kesehatan Dinas Kesehatan Ciamis bahwa Dinas Kesehatan sudah menjalankan monitoring dan evaluasi kepada semua Puskesmas yang berada di Kabupaten

\footnotetext{
${ }^{8}$ Hasil Wawancara dengan Pihak Staff Gudang Farmasi Dinas Kesehatan Kabupaten Ciamis
}

Ciamis. ${ }^{9}$ Monitoring dan evaluasi dari Dinas Kesehatan kami laksanakan rutin untuk meningkatkan mutu standar pelayanan kesehatan, biasanya kami memonitoring dan mengevaluasi 1 (satu) tahun sekali dan per tri wulan (tiga bulan sekali). Dalam monitoring dan evaluasi dalam pelayanan obat tersebut, kami menyamakan data awal dan data kenyataan di lapangan (Perencanaan, pemesanan, penerimaan, penyimpanan menggunakan kartu stok, pendistribusian dan pelaporan) apakah sudah sesuai dengan standar yang telah ditetapkan oleh peraturaan perundang-undangan."

Berdasarkan penelitian di lapangan bahwa Dinas Kesehatan tidak berperan aktif terhadap pembinaan tersebut dikarenakan banyak peserta yang mengeluhkan terhadap pelayanan obat puskesmas tersebut, meskipun menurut hasil wawancara Staff Gudang Farmasi tentang keluhan atas peserta yang tidak mendapatkan pelayanan obat yang ada di fornas di fasilitas kesehatan tingkat pertama (puskesmas) bahwa: "Kami membenarkan memang pada akhir tahun 2015, di puskesmas memang ada kekosongan obat yang berada di fornas, tetapi itu merata di semua puskesmas dikarenakan terjadi kekosongan obat dari pabriknya, obat yang merupakan kekosongan obat diantaranya adalah luminal dan antasida. Luminal terjadi kekosongan obat dari pabriknya sendiri diakibatkan harga bahan baku naik sehingga terjadi lonjakan harga, sehingga untuk memproduksi lagi itu membutuhkan waktu yang lama. Puskesmas apabila terjadi kekosongan obat bukan dari kekosongan pabriknya berarti puskesmasnya sendiri yang

\footnotetext{
${ }^{9}$ Hasil Wawancara dengan Pihak Staff Pelayanan Kesehatan Dinas Kesehatan Kabupaten Ciamis
} 
tidak teliti akan perencanaan, pemesanan, penerimaan, penyimpanan menggunakan kartu stok, pendistribusian dan pelaporannya, kami dari Dinas Kesehatan sebagai penegak hukum memberikan teguran dan pelatihan kembali untuk memperbaiki perencanaan, pemesanan, penerimaan, penyimpanan, pendistribusian serta pelaporannya, karena kami merasakan bahwa di setiap puskesmas yang memegang pelayanan obat tidak sesuai dengan profesinya sehingga kurang faham akan hal tersebut, namun kekosongan obat tersebut dapat diatasi Dinas kesehatan dengan cara mencari puskesmas yang mempunyai kelebihan obat yang terjadi kekosongan sehingga melengkapi ketersediaan obat di puskesmas lain serta melakukan pelatihan-pelatihan untuk mendukung pengetahuan tentang pelayanan obat tersebut."10

Berdasarkan penelitian, kenyataannya Dinas Kesehatan tidak tegas dan kurang aktif dalam mendukung kemajuan pelayanan kesehatan di Puskesmas tersebut, hal ini terlihat bahwa hampir semua Puskesmas yang telah diwawancarai menyatakan bahwa ketika terjadi kekosongan obat, mereka melaporkan ke Dinas Kesehatan tetapi lambatnya feed back dari Dinas Kesehatan sendiri sehingga dari pihak Puskesmas harus memberikan keputusan yang cepat agar tidak terjadi kesalahpahaman tenaga medis dan peserta BPJS Kesehatan. Begitupun faktor sanksi nya tidak terlalu membuat jera terlihat terhadap peraturan yang mengatur dimana hanya berupa teguran dari Dinas Kesehatan Ciamis dan pemutusan hubungan kerjasama dengan BPJS Kesehatan.

10 Hasil Wawancara dengan Pihak Staff Gudang Farmasi Dinas Kesehatan Kabupaten Ciamis
Menurut Hasil Wawancara Kepala Dinas Kesehatan Kabupaten Ciamis bahwa Permenkes Nomor 71 Tahun 2013 Tentang Pelayanan Kesehatan pada Jaminan Kesehatan Nasional belum efektif dikarenakan menurut kami banyak berbenturan dengan berbagai profesi kesehatan, contohnya dimana seharusnya untuk meningkatkan pelayanan obat, maka setiap puskesmas harus memiliki minimal satu apoteker yang mengadakan perencanaan obat, distribusi obat dan pelayanan obat kepada pasien, tetapi kenyataannya dalam 37 Puskesmas hanya ada enam apoteker dan itu termasuk yang ada di Dinas Kesehatan Kabupaten Ciamis. Seharusnya pemerintah mengevaluasi permenkes tersebut dengan adanya sinergis dengan tenaga kesehatan sehingga bukan hanya diutamakan kesehatan peserta tetapi kelangsungan tenaga medis yang dibutuhkan agar terjadi sinkronisasi sistematis prosedur pelayanannya sehingga peserta mendapatkan kepuasan dalam pelayanan tersebut.

Dinas Kesehatan juga tidak memberikan sanksi yang sesuai peraturan dimana apabila Puskesmas tidak memberikan pelayanan obat maka izin operasional dari Puskesmas itu dicabut (Undang-Undang Republik Indonesia Nomor 24 Tahun 2011 Tentang Badan Penyelenggara Jaminan Sosial Pasal 53 ayat 3), sedangkan dalam hasil penelitiannya Dinas Kesehatan hanya memberikan teguran tertulis dan melakukan pembinaan, sedangkan pembinaannya sendiri terhadap puskesmas tidak dilakukan rutin sehingga dapat disimpulkan Permenkes Nomor 71 Tahun 2013 Tentang Pelayanan Kesehatan dalam Jaminan Kesehatan Nasional terhadap pelayanan obat di Puskesmas di Kabupaten Ciamis tidak efektif, 
oleh karena itu tujuan dari Permenkes yaitu peserta memperoleh manfaat pemeliharaan kesehatan dan perlindungan dalam memenuhi kebutuhan dasar kesehatan tidak tercapai.

$\begin{array}{llrr}\text { Faktor Yang } & \text { Mendorong } & \text { Tidak } \\ \text { Dilaksanakannya } & \text { Penegakan } & \text { Hukum } \\ \text { Terhadap Koasissten } & \text { Yang } & \text { Melakukan } \\ \text { Praktik Kedokteran } & \text { Pada } & \text { Pelayanan } \\ \text { Kesehatan Di Klinik } & \text { Pratama } & \text { Wilayah } \\ \text { Kabupaten Banyumas } & & \end{array}$

Faktor-faktor yang mempengaruhi efektifitas hukum menurut Soerjono Soekanto antara lain : ${ }^{11}$

1. Faktor Hukumnya Sendiri

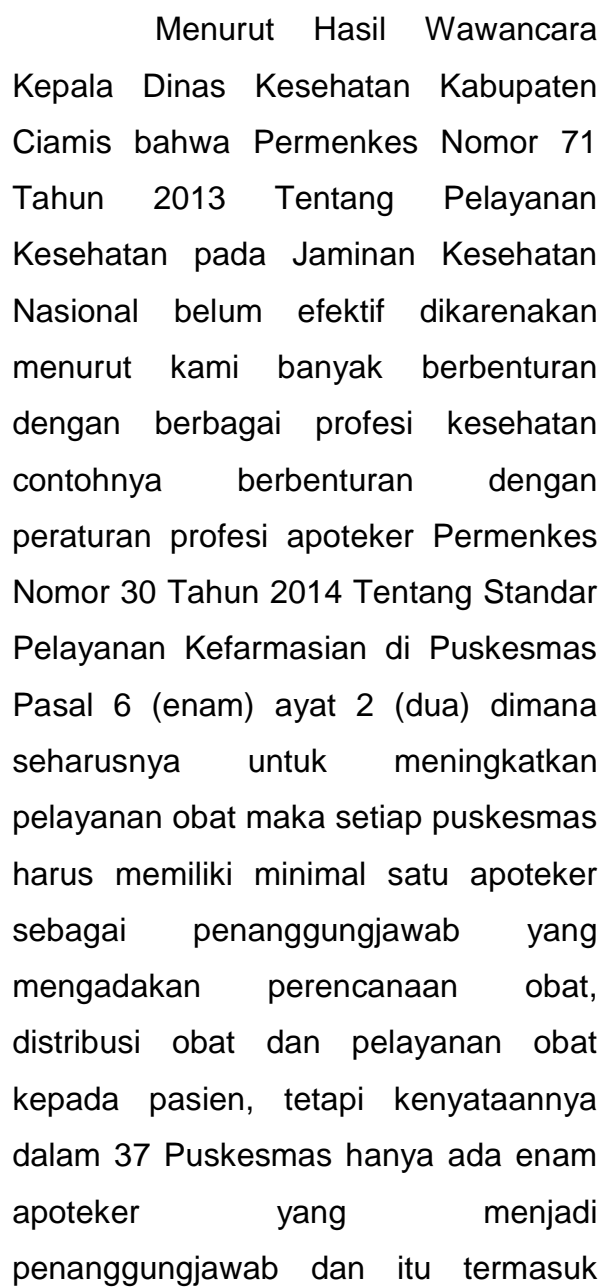

11 Soerjono Soekanto, 1987, Sosiologi Hukum dalam Masyarakat, Jakarta:Rajawali, hlm. 159177

$$
\begin{aligned}
& \text { yang ada di Dinas Kesehatan } \\
& \text { Kabupaten Ciamis. Pemerintah } \\
& \text { seharusya mengevaluasi permenkes } \\
& \text { tersebut dengan adanya sinergis } \\
& \text { dengan tenaga kesehatan sehingga } \\
& \text { bukan hanya diutamakan kesehatan } \\
& \text { peserta tetapi kelangsungan tenaga } \\
& \text { medis yang dibutuhkan agar terjadi } \\
& \text { sinkronisasi sistematis prosedur } \\
& \text { pelayanannya sehingga peserta } \\
& \text { mendapatkan kepuasan dalam } \\
& \text { pelayanan tersebut. } \\
& \text { Berdasarkan penjelasan }
\end{aligned}
$$

tersebut dapat disimpulkan bahwa halhal yang menjadi kendala pada faktor hukumnya sendiri adalah banyak berbenturan dengan berbagai profesi kesehatan, contohnya berbenturan dengan peraturan profesi apoteker Permenkes Nomor 30 Tahun 2014 Tentang Standar Pelayanan Kefarmasian di Puskesmas Pasal 6 ayat 2, dimana seharusnya untuk meningkatkan pelayanan obat maka setiap puskesmas harus memiliki minimal satu apoteker sebagai penanggungjawab yang mengadakan perencanaan obat, distribusi obat dan pelayanan obat kepada pasien, tetapi kenyataannya dalam 37 Puskesmas hanya ada enam apoteker yang menjadi penanggungjawab dan itu termasuk yang ada di Dinas Kesehatan Kabupaten Ciamis, sehingga untuk pelaksanaan dalam hukumnya sendiri tidak dijalankan dikarenakan banyak berbenturan dengan peraturan profesi lain.

2. Faktor Penegak Hukum 
Berdasarkan hasil wawancara dengan BPJS Kesehatan, Dinas Kesehatan dan Puskesmas sendiri bahwa, sebagai penegak hukum belum dapat menjalankan peraturan tersebut dikarenakan banyak kendala terutama berbenturan dengan kebijkan-kebijakan sendiri di tiap daerahnya, sehingga pada saat yang terjadi di lapangan ketika terjadi keluhan dari peserta secara peraturan memang harus dilakukan sanksi kepada Faskes tingkat pertama oleh Dinas Kesehatan untuk pencabutan izin operasionalnya, sedangkan Dinas Kesehatan sendiri kenyataannya hanya memberikan teguran lisan dan tertulis saja dan melakukan pembinaan. Pembinaan itu juga dilakukan hanya dilakukan tiap 6 bulan sekali tidak dalam rentang 1 bulan sekali. Dinas Kesehatan dan BPJS Kesehatan tidak langsung memutuskan kerja sama kerja dengan puskesmasnya karena banyak kebijakan yang harus didiskusikan dengan Dinas Kesehatan setempat dikarenakan faktor wewenang pengawasan dan pembinaan dari

Dinas Kesehatan tersebut.

Berdasarkan penjelasan tersebut dapat disimpulkan bahwa hal-hal yang menjadi kendala pada faktor penegak hukum adalah berbenturan dengan kebijkan-kebijakan sendiri di tiap daerahnya. Setiap daerah tidak dapat disamakan kebutuhan dan kondisinya sehingga pihak-pihak terkait penegak hukumnya belum dapat menaati peraturan tersebut sepenuhnya.

3. Faktor Sarana atau Fasilitas

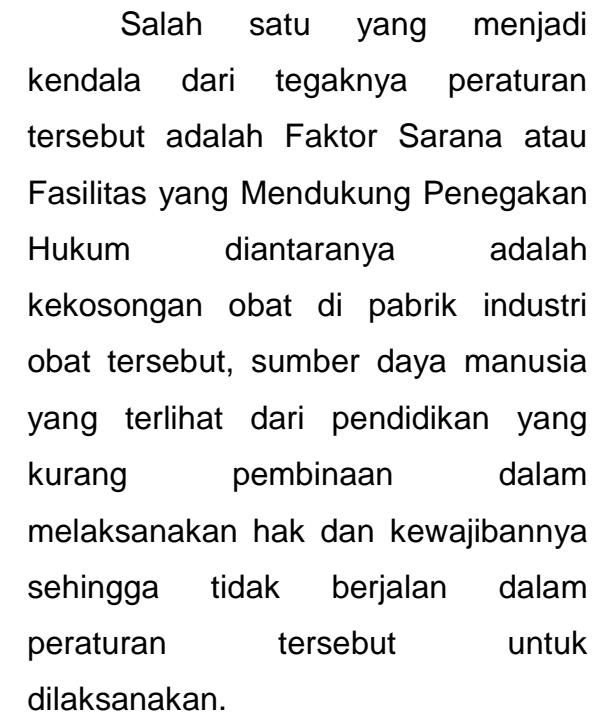

4. Faktor Masyarakat Salah satu yang menjadi kendala dari tegaknya peraturan tersebut adalah Faktor Masyarakat itu sendiri diantaranya adalah bahwa mereka menganggap petugas dan pejabatnya tidak melaksanakan peraturan itu sendiri sehingga mereka mengganggap petugas dan pejabat berwenang tidak taat dalam peraturan maka dari itu karena ada kekecewaan seperti itu peserta BPJS Kesehatan akan cenderung berdampak terhadap ketidaktaatan dalam memenuhi peraturan dalam pembayaran iuran tiap bulannya.

\section{PENUTUP}

\section{Kesimpulan}

Berdasarkan pada hasil penelitian dan pembahasan dapat diambil kesimpulan sebagai berikut.

a. Permenkes Nomor 71 Tahun 2013 Tentang Pelayanan Kesehatan terhadap Pelayanan Obat di Puskesmas Kabupaten Ciamis belum efektif, karena dilihat dari tingkat ukuran ketaatan suatu aturan 
perundang-undangan, terlihat subjek hukum yaitu puskesmas di Kabupaten Ciamis dari 6 (enam) puskesmas terdapat 2 (dua) puskesmas yang taat melaksanakan pelayanan obat dalam peraturan tersebut, namun ada 4 (empat) puskesmas yang tidak taat dalam melaksanakan pelayanan obat dalam peraturan tersebut, sehingga tujuan dari Permenkes Nomor 71 Tahun 2015 yaitu peserta memperoleh manfaat pemeliharaan kesehatan dan perlindungan dalam memenuhi kebutuhan dasar kesehatan itu tidak tercapai.

b. Faktor penghambat pelaksanaan Pelaksanaan Permenkes Nomor 71 Tahun 2013 yaitu faktor hukumnya sendiri dimana aturan atau hukumnya sendiri berbenturan dengan berbagai profesi kesehatan, faktor Sarana atau Fasilitas yang Mendukung, dimana kendalanya diantaranya adalah kekosongan obat di pabrik industri obat tersebut, sumber daya manusia yang terlihat dari pendidikan yang kurang pembinaan dalam melaksanakan hak dan kewajibannya sehingga tidak berjalan peraturan tersebut untuk dilaksanakan.

\section{Saran}

Saran-saran yang dapat dibuat berdasarkan hasil penelitian dan pembahasan sebagai berikut.

a. Faskes (Fasilitas Kesehatan) apabila mengalami kendala ketersediaan obat seharusnya tidak hanya diam menunggu keputusan Dinas Kesehatan saja, namun dapat menghubungi langsung Direktorat
Bina Obat Publik atas kendala ketersediaan obat tersebut, sehingga kebutuhan peserta BPJS Kesehatan terhadap pelayanan obat dapat terpenuhi.

b. Jenis obat tidak tersedia dalam Fornas dan harganya tidak terdapat dalam ekatalog, maka seharusnya apoteker dalam pengadaannya dapat menggunakan mekanisme pengadaan yang lain sesuai dengan perundangundangan yang berlaku.

c. Permenkes Nomor 71 Tahun 2013 juga seharusnya dievaluasi kembali dikarenakan ada banyak kendala, khususnya kurang sinergis antara peraturan BPJS sendiri, organisasi profesi (Peraturan Pemerintah Nomor 51 Tahun 2009 Tentang Pekerjaan Kefarmasian), maka dari itu seharusnya didalam Permenkes Nomor 71 Tahun 2013 ini dicantumkan stnadar pelayanan kefarmasian sehingga dapat menigkatkan mutu pelayanan kesehatan.

d. Dinas Kesehatan sebagai penegak hukum seharusnya lebih tegas dalam menyikapi ketidaktaatan subjek hukum (Puskesmas).

\section{DAFTAR PUSTAKA}

\section{Buku}

Abdurrahma, Muslan, 2009, Sosiologi dan Metode Penelitian Hukum, UMM Press, Malang.

Ashofa, Burhan, 2004,Metode Penelitian Hukum, PT Rineka Cipta, Jakarta.

Asyhadie, Zaeni, 2007, Aspek-Aspek Hukum Jaminan Sosial Tenaga Kerja di Indonesia, Rajawali Pers, Mataram.

Dwiyanto, Agus, 2008, Mewujudkan Good Governance Melalui Pelayanan Publik . 
Gadjah Mada University Press, Yogyakarta.

Efendi, Ferry dan Makhfudli, 2009, Keperawatan Kesehatan Komunitas: Teori dan Praktik dalam Keperawatan,Salemba Medika, Jakarta.

Pohan, Imbalo S, 2004, Jaminan Mutu Layanan Kesehatan:Dasar-Dasar Pengertian dan Penerapan, Penerbit Buku Kedokteran EGC,Jakarta.

Soekanto, Soerjono, 1985, Efektivikasi Hukum dan Sanksi- Sanksi Remadja Karya, Bandung.

Soekanto, Soerjono, 1987, Sosiologi Hukum dalam Masyarakat, Rajawali,Jakarta.

Soekanto, Soerjono, 1989, Suatu Tinjauan Sosiologis Hukum Terhadap Masalah-Masalah Sosial, Alumni, Bandung.

Sugiyono, 2008,Memahami Penelitian Kualitatif, Alfabeta, Bandung.

Sunggono, Bambang, 2006, Metode Penelitian Hukum,PT Raja Grafindo Persada, Jakarta.

Zainudin, Ali, 2007, Sosiologi Hukum. Sinar Grafika, Jakarta.

Zainal, Ashikin dan Amiruddin, 2004, Pengantar Metode Penelitian Hukum. PT Raja Grafindo Persada, Jakarta.

\section{Peraturan Perundang-Undangan:}

Undang-Undang Dasar 1945

Peraturan Pemerintah Republik Indonesia Nomor 51 Tahun 2009 Tentang Pekerjaan Kefarmasian

Undang-Undang Republik Indonesia No. 40 Tahun 2004 Tentang Sistem Jaminan Sosial Nasional

Undang-Undang No. 24 Tahun 2011 Tentang Badan Penyelenggara Jaminan Sosial.

Peraturan Presiden No. 12 Tahun 2013 Tentang Jaminan Kesehatan
Undang-Undang No. 71 Tahun 2013 Tentang Pelayanan Kesehatan Pada Jaminan Kesehatan Nasional

Peraturan Menteri Kesehatan No. 28 Tahun 2014 Tentang Pedoman Pelaksanaan Program Jaminan Kesehatan Nasional

Peraturan Presiden No. 32 Tahun 2014 Tentang Pengelolaan dan Pemanfaatan Dana Kapitasi Jaminan Kesehatan nasional pada Fasilitas Kesehatan Tingkat Pertama

Peraturan Menteri Kesehatan Republik Indonesia No. 30 Tahun 2014 Tentang Standar Pelayanan Kefarmasian di Puskesmas

Keputusan Bupati Ciamis Nomor 440/Kpts.132-Huk/2016 Tentang Penetepan Kategori Unit Pelaksana Tekhnis Dinas Kesehatan Pusat Kesehatan Masyarakat di Kabupaten Ciamis sebagai Pusat Kesehatan Masyarakat dengan Kategori Rawat Inap dan Pusat Kesehatan Masyarakat dengan Kategori Non Rawat Inap. 